\title{
Microplastics from degradation of tires in sewer networks of the city of Riobamba, Ecuador
}

\author{
Marcel Paredes ${ }^{1 \dagger}$, Rafaela Viteri ${ }^{2,3}$, Tito Castillo ${ }^{1}$, Cristian Caminos ${ }^{1}$, Christian Ebere Enyoh ${ }^{4}$ \\ ${ }^{1}$ Universidad Nacional de Chimborazo, Av. Antonio José de Sucre, Riobamba, Ecuador \\ ${ }^{2}$ Escuela Superior Politécnica de Chimborazo, South Panamericana Sur, Km 1 1⁄2, Riobamba, Ecuador \\ ${ }^{3}$ Universidad Politécnica de Madrid, Ramiro de Maeztu Street, 7, 28040 Madrid, España \\ ${ }^{4}$ Group Research in Analytical Chemistry, Environment and Climate Change (GRACE\&CC), Department of Chemistry, Imo State University (IMSU), \\ PMB 2000 Owerri, Imo State, Nigeria
}

\section{ABSTRACT}

Microplastics are small synthetic particles that come from petroleum derivatives, are difficult to degrade and their origin is found in industrial activity and domestic consumption, even in tires. The presence of small particles $(0.1 \mu \mathrm{m}$ to $<5 \mathrm{~mm})$ of plasticizer Bis (2-ethylhexyl) phthalate (DEHP) and synthetic rubber, which due to their size and origin are called microplastics. The friction occurs between the asphalt in contact with the tires of cars generate the detachment of small residues of it, these residues come to contain a DEHP element. Simple residual water samples were carried out in the different sewage collectors in Riobamba city, $250 \mathrm{~mL}$ of each of these samples were filtered using vacuum suction equipment, to then examine the filters with a visual microscope. Obtaining as a result that $80 \%$ of the samples taken and analyzed in the laboratory contain the clear presence of DEHP plasticizer from the friction of tires (confirmed by the Principal Component Analysis) with the asphalting of the streets of the city of Riobamba, and that only $20 \%$ of the samples analyzed do not present DEHP plasticizer of this type, generating a medium risk for the health of humans and aquatic animals in the sector.

Keywords: Additive, Microcontamination, Microplastics, Plasticizer, Tires

\section{Introduction}

Since the sixties of the last century the production of plastics has grown almost 9\% each year. In 2015, 322 millions of tons were produced according to UN data. Later part of plastic ends in the environment, particularly in the marine environment, around eight million tons per year [1]. The water, microorganisms and sunlight break down the plastic until is reduced to small particles of a few microns in length [2]. Some are so small that they are ingested by marine organisms due to their similar size with microplankton, and microplastics (MPs), also contain attached organic pollutants [3]. MPs are small synthetic particles that come from petroleum derivatives, are difficult to degrade and their origin is in industrial activity and domestic consumption, being present in detergents, toothpastes, salt, in skin products such as exfoliants and sunscreens and even many synthetic fibers from clothing and tires [4]. The problem is that these materials are toxic, abrasive and difficult to treat due to their small size [5]. But the question that science must still answer is from what amount ingested plastic can be a problem for human health. There are two risks, on the one hand the impact of the physical presence of plastic particles and, on the another, the possible toxicity of its chemical components. Studies carried out like "Orb Media", in collaboration with the Universities of New York and Minnesota, they determined that MPs are omnipresent in the human food chain. According to this study, it was possible to detect the presence of MPs in the feces of people who lives in Europe, Russia and Japan, different types of plastic were found in eight volunteers from this pilot study, presented during a gastroenterology congress in Vienna as a world first [6]. For a week, five women and three men, ages 33 to 65, residing in Finland, Netherlands, Great Britain, Poland, Italy, Russia, Japan, and Austria, wrote down what they ate, the size of the plastic samples found in their stool varies from 50 to 500 micrometers, more or less the thickness of a hair.
This is an Open Access article distributed under the terms of the Creative Commons Attribution Non-Commercial License (http://creativecommons.org/licenses/by-nc/3.0/) which permits unrestricted non-commercial use, distribution, and reproduction in any medium, provided the original work is properly cited.

Copyright (C) 2021 Korean Society of Environmental Engineers
Received May 26, 2020 Accepted September 09, 2020

${ }^{\dagger}$ Corresponding author

Email: marcelparedes@unach.edu.ec

Tel: $+(593) 998903598$

ORCID: 0000-0002-3762-9633 
Currently assumed they were ingested through seafood that the volunteers consumed, but also from the water in plastic bottles, drinks, or food wrapped in plastic [7]. These products correspond to daily consumption and are in contact with water, the bad disposal of waste also causes large amounts of MPs to be poured into the sewer system [8]. The MPs found in drinking water collection and distribution networks in the city of Riobamba are a constant concern, since the presence of this contaminant in water resources is evident [9]. That is why the concern becomes bigger. In Riobamba city due to the presence of an increasing vehicular flow, the friction between the asphalt in contact with tires of the cars generates the detachment of small residues of it, these residues come to contain an element called plasticizer of di (2-ethylhexyl) phthalate (DEHP) [10], this is a chemical polymer in liquid state derived from petroleum, is commonly added to plastics to make them more flexible, this additive is incorporated in the manufacturing process of the tires and turns out to be very harmful for the ecosystem and for the human being since it is a genotoxic, carcinogenic element [11]. $60 \%$ of synthetic rubber and $75 \%$ of natural rubber is used in the manufacture of tires and related products [12]. According to data provided by Beliczky and Fajen, the type of rubber used for the manufacture of tires until the year 1993 is natural rubber, however this was modified and currently polymers are used as: Styrene-butadiene (SBR), Polybutadiene (BR), and in very few quantities Polychloroprene (CR), which being modified compounds are more difficult to degrade and whose problem is the chemicals and other elements added as DEHP type plasticizers [13], This additive is compatible with CR, SBR and BR type rubbers, the most widely used rubber families in the tire industry. The friction between the asphalt in contact with the tires of the cars generates the detachment of small residues [14]. Adding of physical factors such as wind [15] and water tend to move into gutters and mix with domestic and industrial wastewater and in the end may appear in the various sewer systems, there is direct contact of these waters with the biological environment becoming a major problem for the habitants of the city [16]. Therefore, the aim is to determine the percentage of source
MPs from friction-degraded tires in sewer systems with the city of Riobamba as a case study.

\section{Materials and Methods}

The study area is located in the city of Riobamba, for which it coordinated with the Municipal Company of Potable Water and Sewerage of the city of Riobamba (EP EMAPAR), which provided the respective information of the sewerage networks that exist in the city. There are 41 sewage discharges, however for this investigation 28 discharges are discarded that are purely domestic since they do not have contact with tire waste, resulting in 12 sampling points in which different water samples were taken in order to detect the presence of microplastic from tires in them.

\subsection{Sample Calculation}

The sample size was made with data obtained from the Department of Vehicle Registration - Directorate of Mobility, Traffic and Transport Management of the GADR, 2019, which provided the exact number of vehicles registered for the year 2018 and 2019. However, as the current year was not yet over, it was considered to use the data on the number of vehicles registered for 2018 for this research. For the year 2018 the total number of vehicles registered in the city of Riobamba was 48,747 , this numerical value is considered as our population to analyze. To calculate the number of samples to be analyzed [17] we used the sample size Eq. (1).

$$
\text { sample size }=\frac{\frac{z^{2} \cdot p(1-p)}{e^{2}}}{1+\left(\frac{z^{2} \cdot p(1-p)}{e^{2} \cdot N}\right)}
$$

$\mathrm{N}=$ population size,

$\mathrm{e}=$ margin of error,

$\mathrm{p}=$ probability of success,

$\mathrm{z}=\mathrm{z}$-score

Table 1. Discharges of Sewage Tributaries to Receiving Bodies

\begin{tabular}{|c|c|c|c|c|c|}
\hline No & Coord. $\mathbf{x}$ & Coord. $\mathbf{y}$ & Receiving Body & Location & Observations \\
\hline 1 & 758,451 & 981,5576 & Chibunga river & $185 \mathrm{~m}$ from the municipal greenhouse & Waste water discharge \\
\hline 2 & 758,622 & 981,5549 & Chibunga river & Urb. Agrotouristic farms & Dry \\
\hline 3 & 759,411 & 981,5244 & Chibunga river & Quinta Macaji & Waste water discharge \\
\hline 4 & 759,495 & 981,5101 & Chibunga river & Under the Batan bridge & Dry \\
\hline 5 & 759,775 & 981,4766 & Chibunga river & $60 \mathrm{~m}$ before the pte. La Primavera & Covered \\
\hline 6 & 759,917 & 981,3889 & El bunque ravine & $120 \mathrm{~m}$ before the pte. Yaruquies & Dry \\
\hline 7 & 759,954 & 981,3895 & El bunque ravine & $80 \mathrm{~m}$ before the pte. Yaruquies & Waste water discharge \\
\hline 8 & 761,719 & 981,2859 & Chibunga river & At the end of the ecological park & Waste water discharge \\
\hline 9 & 758,925 & 981,3246 & Puctus ravine & Street extension Pedro Duchi & Waste water discharge \\
\hline 10 & 758,595 & 981,9220 & Las abras ravine & At the end of the coop. Diocesis & Dry \\
\hline 11 & 758,678 & 981,9059 & Las abras ravine & At the end of the Sector the Providencia & Impossible access \\
\hline 12 & 758,718 & 981,8837 & Las abras ravine & $15 \mathrm{~m}$ from the pte. From the urb.Caminos del Sol & Impossible access \\
\hline $13-42$ & - & - & Chibunga river & Between bridge La Primavera individual houses & Household water discharges only \\
\hline
\end{tabular}


After applying the equation with a 95\% confidence level, 51 samples were obtained for analysis. There are 12 sewerage distribution networks available for sampling, it was decided to take 5 samples from each distribution network as shown in Fig. 1 at different times to obtain a reliable laboratory result. Field visits were made to all 12 sewerage discharge points to find out the conditions in which they are located.

\subsection{Sample Collection and Processing}

The water quality standard was used for sampling. Sampling. Part 3: Conservation and handling of water samples [18]. A field card was used for each wastewater sample taken, in order to facilitate the data collection and verify the correct process given for the sampling, which consists of the following data: letterhead of the educational institution, geographic coordinates, date, name of the sewage system, among other data. Once the samples have been taken, they are analysed using the synthetic mycoparticle detection methodology proposed by Paredes et al. [9], in which a vacuum suction pump was used for the purpose of filtering the waste water, as opposed to the Rose Bengal was not used for this research since the tyres contain "black carbon" which is detected by the visual microscope without the need for a dye that gives the MPs

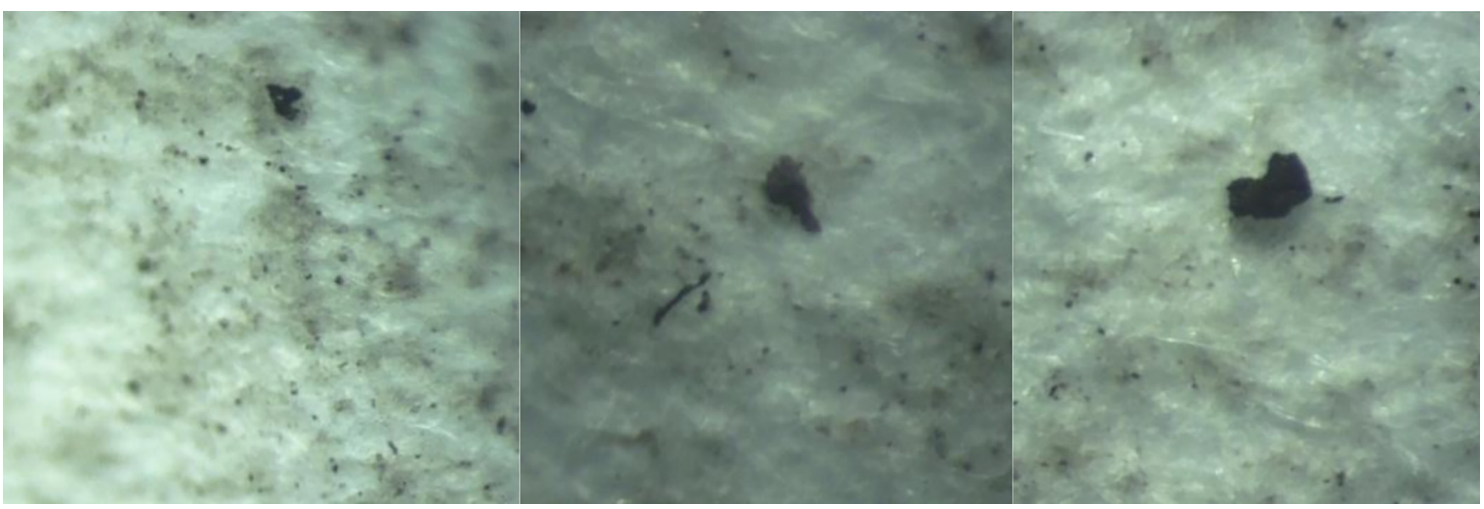

Fig. 1. DEHP plasticizer present in APR-2 sewerage water samples (Quinta Macají). Zoom 4,8:1.
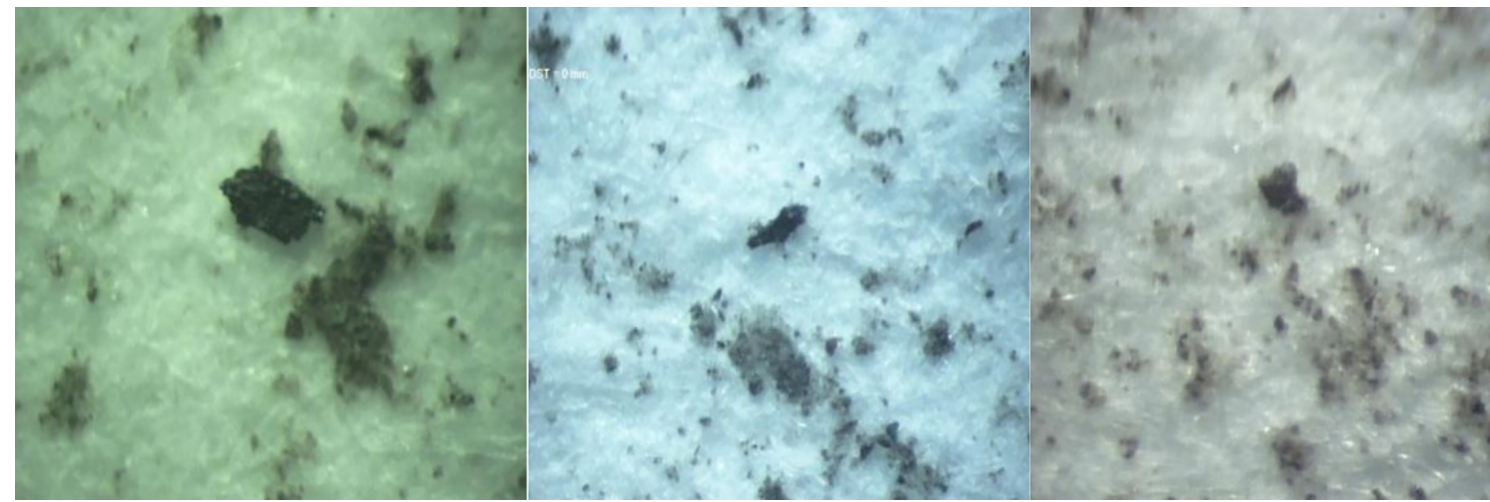

Fig. 2. DEHP plasticizer present in APR-3 sewerage water samples. Zoom 4,8:1.

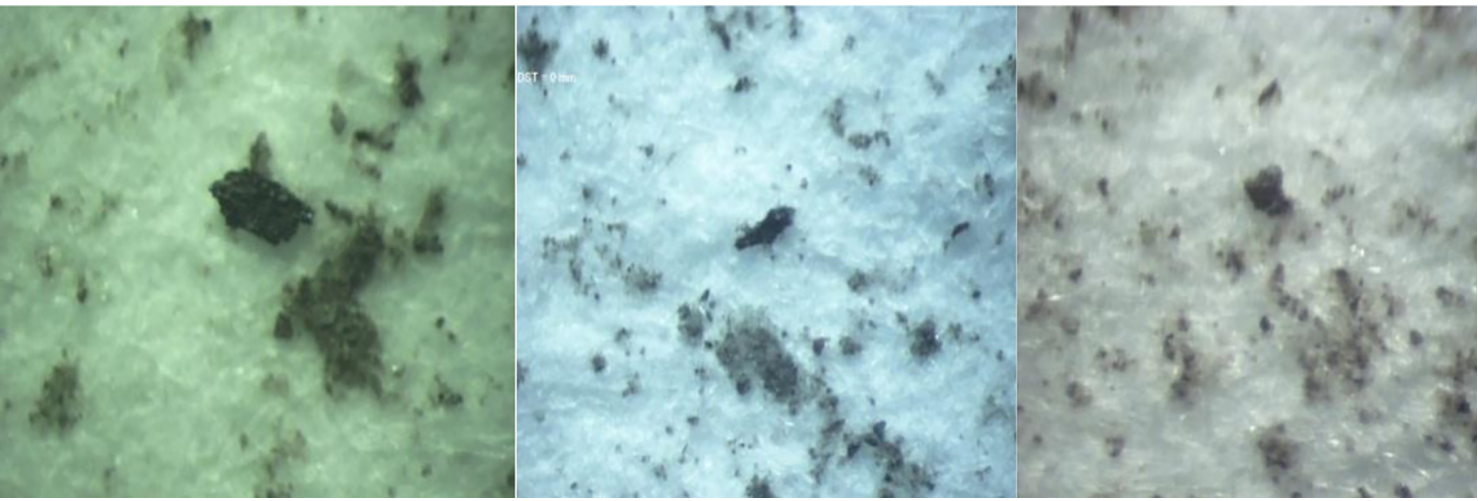

Fig. 3. DEHP plasticizer present in sewage water samples Batán. Zoom 4,8:1 


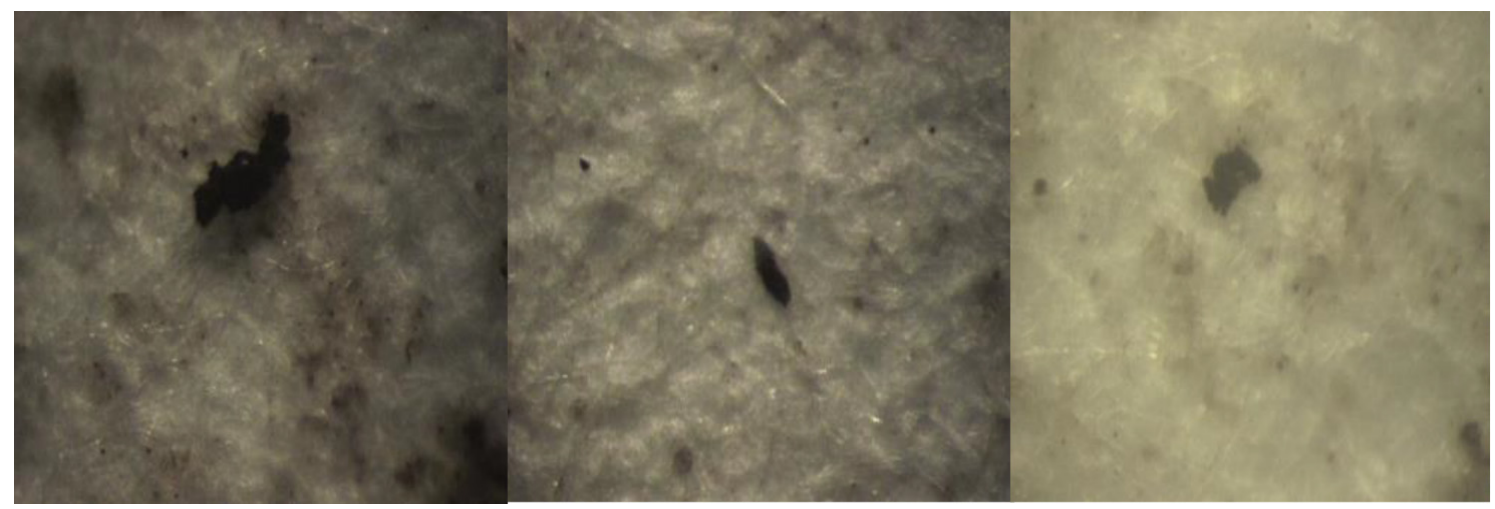

Fig. 4. DEHP plasticizer present in the samples of sewage water collector Emisario Chibunga. Zoom 4,8:1.

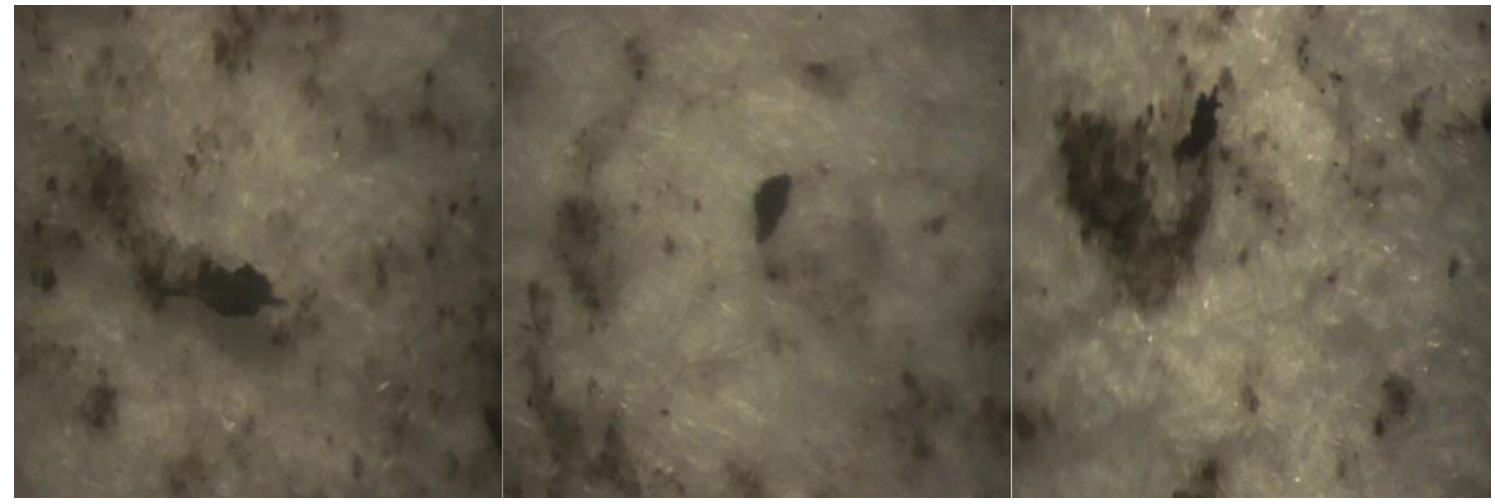

Fig. 5. DEHP plasticizer present in the Yaruquies sewage water samples. Zoom 4,8:1.

refractoriness. DEPH particles were degraded to compare them with those obtained in the samples and were processed through a 2-4 $\mu \mathrm{m}$ pore filter. In the laboratory we proceded to pour out $250 \mathrm{~mL}$ of water sample by vacuum filtration through a cellulose filter of $37 \mathrm{~mm}$ diameter with a pore size of 2 to $4 \mu \mathrm{m}$, then this filter was placed in a labeled Petri dish. After a drying time of 5 min, a Visual Microscope (iVu 7000. With 7.1 Mpx) with an integrated camera was used to check for the presence of MPs which according to $[18,19]$, are set in sizes from $5 \mathrm{~mm}$ to $1 \mu \mathrm{m}$. Once the results of this procedure were analyzed and the MPs from the tire degradation were identified, the number of filters containing these contaminants was recorded in order to calculate the percentage of samples with MPs.

\subsection{Data Analysis}

Data analysis was conducted using IBM SPSS Statistics Version 20. Principal component analysis were computed for source identification.

\section{Results and Discussions}

For the investigation we took into account what was indicated by Rojo Nieto \& Montoto [19], who establish that the classification of plastic particles according to their size is of a range between $5 \mathrm{~mm}$ to $1 \mu \mathrm{m}$ to denominate it microplastic, it should be taken into account that the analyzed samples are experimental samples that contain elements considered as DEHP type plasticizers from 2 to 6 field units and other polymers such as CR, BR, SBR, for every $250 \mathrm{~mL}$ of filtered water as indicated below.

\subsection{Presence of DEHP Plasticizer in Collectors}

The following data were obtained for the APR-2 collector, APRcollector, Batán collector, Emisario Chibunga collector and Yaruquies collector, whose wastewater discharge is to be deposited in the waters of the Chibunga River.

Depending on the number of particles found in water sources, is relatively low according to [2], not aggressive to human health, but the samples 4 are dangerous for marine animals such as fish, shellfish, bivalves or others [20]. Comparing mean results $(1.6 \pm 1.4 \mathrm{MP} / 250 \mathrm{~mL}$ to $3 \pm 2.19 \mathrm{MP} / 250 \mathrm{~mL})$ obtained with other studies which adopted similar method as this study, lower concentrations were reported in Finland $1 \pm 1.1 \mathrm{MP} / \mathrm{L}$ [21] and $0.04-1.2 \mathrm{MP} / \mathrm{L}$ [22]. Further, it was higher than concentration reported in the US, $0 \mathrm{MP} / \mathrm{L}$ [23] while lower to the ones reported in Netherland $65 \pm 67 \mathrm{MP} / \mathrm{L}$ [24]. After the results obtained, it can be said that $80 \%$ of the samples taken and analyzed in the laboratory contain the clear presence of DEHP Plasticizer from the friction of tires with the asphalt of the streets of Riobamba City, and only $20 \%$ of the samples analyzed do not present DEHP Plasticizer of this type. The data obtained after the observation of the filters with the visual microscope (iVu 7000. With 7.1 
Table 2. Data, Presence of DEHP Plasticizer in Collectors

\begin{tabular}{|c|c|c|c|c|c|c|}
\hline \multirow{2}{*}{ Sample No. } & \multirow{2}{*}{ Collector } & \multirow{2}{*}{ Receiving Body } & \multirow{2}{*}{ Collector's Section } & \multicolumn{3}{|c|}{ Presence Of Plasticizer Dehp } \\
\hline & & & & Field units (No. of particles/ $250 \mathrm{~mL}$ ) & YES & NO \\
\hline M1 & APR-2 & Chibunga river & $1.8 \times 1.5 \mathrm{~m}$ & 3 & $\mathrm{X}$ & \\
\hline M2 & APR-2 & Chibunga river & $1.8 \times 1.5 \mathrm{~m}$ & 3 & $\mathrm{X}$ & \\
\hline M3 & APR-2 & Chibunga river & $1.8 \times 1.5 \mathrm{~m}$ & 6 & $\mathrm{X}$ & \\
\hline M4 & APR-2 & Chibunga river & $1.8 \times 1.5 \mathrm{~m}$ & 4 & $\mathrm{X}$ & \\
\hline M5 & APR-2 & Chibunga river & $1.8 \times 1.5 \mathrm{~m}$ & 3 & $\mathrm{X}$ & \\
\hline M6 & APR-2 & Chibunga river & $1.8 \times 1.5 \mathrm{~m}$ & 0 & & $\mathrm{X}$ \\
\hline M1 & APR-3 & Chibunga river & $1.8 \times 1.8 \mathrm{~m}$ & 0 & & $\mathrm{X}$ \\
\hline M2 & APR-3 & Chibunga river & $1.8 \times 1.8 \mathrm{~m}$ & 4 & $\mathrm{X}$ & \\
\hline M3 & APR-3 & Chibunga river & $1.8 \times 1.8 \mathrm{~m}$ & 4 & $\mathrm{X}$ & \\
\hline M4 & APR-3 & Chibunga river & $1.8 \times 1.8 \mathrm{~m}$ & 0 & & $\mathrm{X}$ \\
\hline M5 & APR-3 & Chibunga river & $1.8 \times 1.8 \mathrm{~m}$ & 2 & $\mathrm{X}$ & \\
\hline M6 & APR-3 & Chibunga river & $1.8 \times 1.8 \mathrm{~m}$ & 2 & $\mathrm{X}$ & \\
\hline M1 & Batán & El Bunque ravine & $200 \mathrm{~mm}$ & 0 & & $\mathrm{X}$ \\
\hline M2 & Batán & El Bunque ravine & $200 \mathrm{~mm}$ & 3 & $\mathrm{X}$ & \\
\hline M3 & Batán & El Bunque ravine & $200 \mathrm{~mm}$ & 2 & $\mathrm{X}$ & \\
\hline M4 & Batán & El Bunque ravine & $200 \mathrm{~mm}$ & 0 & & $\mathrm{X}$ \\
\hline M5 & Batán & El Bunque ravine & $200 \mathrm{~mm}$ & 2 & $\mathrm{X}$ & \\
\hline M6 & Batán & El Bunque ravine & $200 \mathrm{~mm}$ & 3 & $\mathrm{X}$ & \\
\hline M1 & Emisario Chibunga & Chibunga river & $700 \mathrm{~mm}$ & 2 & $\mathrm{X}$ & \\
\hline M2 & Emisario Chibunga & Chibunga river & $700 \mathrm{~mm}$ & 2 & $\mathrm{X}$ & \\
\hline M3 & Emisario Chibunga & Chibunga river & $700 \mathrm{~mm}$ & 0 & & $\mathrm{X}$ \\
\hline M4 & Emisario Chibunga & Chibunga river & $700 \mathrm{~mm}$ & 5 & $\mathrm{X}$ & \\
\hline M5 & Emisario Chibunga & Chibunga river & $700 \mathrm{~mm}$ & 6 & $\mathrm{X}$ & \\
\hline M6 & Emisario Chibunga & Chibunga river & $700 \mathrm{~mm}$ & 3 & $\mathrm{X}$ & \\
\hline M1 & Yaruquies & Puctus revine & $1.2 \times 0.9 \mathrm{~m}$ & 2 & $\mathrm{X}$ & \\
\hline M2 & Yaruquies & Puctus revine & $1.2 \times 0.9 \mathrm{~m}$ & 3 & $\mathrm{X}$ & \\
\hline M3 & Yaruquies & Puctus revine & $1.2 \times 0.9 \mathrm{~m}$ & 3 & $\mathrm{X}$ & \\
\hline M4 & Yaruquies & Puctus revine & $1.2 \times 0.9 \mathrm{~m}$ & 4 & $\mathrm{X}$ & \\
\hline M5 & Yaruquies & Puctus revine & $1.2 \times 0.9 \mathrm{~m}$ & 2 & $\mathrm{X}$ & \\
\hline M6 & Yaruquies & Puctus revine & $1.2 \times 0.9 \mathrm{~m}$ & 3 & $\mathrm{X}$ & \\
\hline
\end{tabular}

Mpx), and calculated the percentages of DEHP type plasticizers, we have the result of plasticizing element together with the various polymers (SBR, BR, and CR), used for the manufacture of tires in the stages of mixing compounds in Banbury malaxator and vulcanize [25], due to their degree of toxicity, their stony origins, their method of manufacture and their sizes (between 0.5 and $2 \mathrm{~mm}$ ) are considered as secondary MPs, since they come from the decomposition and fragmentation of a macroplastic that is the tyre [22]. Any type of microplastic or macroplastic structure presents a great risk to the health in animals and people [5]. Even more when a city like Riobamba does`n have a water treatment plant.

\subsection{Source Identification- Principal Component Analysis}

To determine the precise source(s) of particles in the sewage water; we conducted a principal component analysis following standard procedures [26]. We used the varimax rotation with Kaiser Normalization because it better explained the possible groups or sources that influence the system and maximize the sum of the variance of the factor coefficients [26]. The factor loadings for particles in rotated space are shown in Fig. 6. Two components were extracted based on eigen value $>1$, best described the sources.

According to [26] and [27], components loadings values of $>$ 0.75 , 0.75-0.50, and 0.50-0.30 were classified as "strong", "moderate", and "weak", respectively. The PC1 explained $41.423 \%$ 


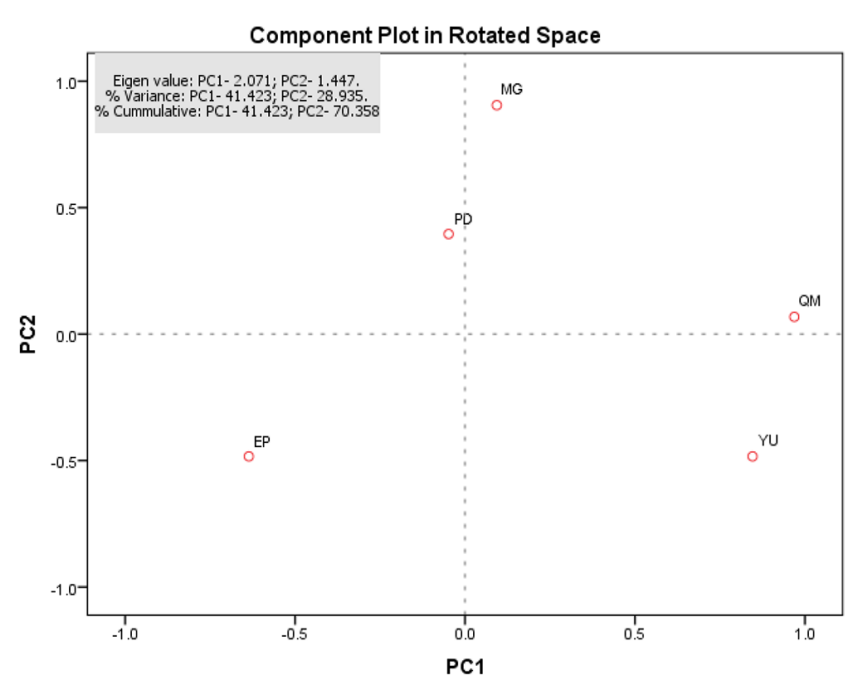

Fig. 6. Principal Component Matrix using varimax rotation of particles in the sewer water from different points. MG: $185 \mathrm{~m}$ from the municipal greenhouse; QM: Quinta Macaji; YU: $80 \mathrm{~m}$ before the pte. Yaruquies; EP: At the end of the ecological park; PD:Street extension Pedro Duchi.

of total variance and was found to be positively correlated to MG, QM and YU (0.094 to 0.969) while PC2 explained $28.935 \%$ of total variance with weak correlation to PD and EP. Overall, most $(60 \%)$ of the study points showed positive relating to degradation of tires from road frictions. Other likely source(s) could be from atmospheric deposition [15], which may account for the other $40 \%$ in PC2.

\section{Conclusions}

Based on the results obtained in the investigation, after collected and analyzed 30 wastewater samples in different sewage collectors in Riobamba city, is established that in 24 of the samples analyzed there is evidence of the presence of MPs, which represents $80 \%$ of the total samples analyzed in the laboratory. Since there are no standardized parameters for the amount of microplastics allowed to be discharged into water bodies, but based on toxicity studies carried out by different organizations, it can be concluded that the amount and type of MPs found in the samples analyzed represent an average risk to the health of animals living in aquatic environments as well as to humans. In addition, the lack of standardized parameters and specific techniques for identifying MPs makes it difficult to establish the chemical and physical properties of the particles found, which is why it was not possible to give a high degree of reliability to the results obtained. Further research should apply other methods for the characterization of microplastics in which the chemical properties of each particle found can be identified. The source of contamination of wastewater with MPs comes from the substitution of natural rubber by synthetic rubber (SBR, CR and BR) in the manufacture of tires as well as the use of different additives such as DEHP type plasticizers, oil-based polymers that are toxic and carcinogenic. It should be noted that the samples that do not present data on the amount of DEHP plasticizer were taken in the morning on days with little rain, which is a possible cause of not finding contaminating elements in these samples, since the residues that are released from the tires tend to remain on the asphalt of the street and others due to density are displaced by the wind, while other less dense elements remain in the asphalt and are transported to the gutters by the action of rain and end up being mixed with wastewater, which is why only residual water discharges - rainwater - were analysed and purely domestic discharges were ruled out. The presence of MPs in the Riobamba sewer system from the friction of the tire with the asphalt is totally evident, which shows the risk that exists when there is no control of them since the different companies that manufacture these tires do not report the content that their products have and the possible risk that can be generated for the environment and living beings.

\section{Author Contributions}

M.P. (Professor), director of the research project and author of the research lines. R.V. (Associate external Professor) wrote and revised the manuscript. T.C. (Professor) wrote and revised the manuscript. C.C. (Engineering student) experimental trials. C.E.E. (Associate external Professor) wrote and revised the manuscript.

\section{References}

1. Chen X, Yan N. A brief overview of renewable plastics. Mater Today Sustain. 2020;7-8;100031-41.

2. Rochman CM, Chelsea M, Tahir A, et al. Anthropogenic debris in seafood: Plastic debris and fibers from textiles in fish and bivalves sold for human consumption. Sci. Rep. 2015;5;1-10.

3. Ding L, Mao R, Ma S, Guo X, Zhu L. High temperature depended on the ageing mechanism of microplastics under different environmental conditions and its effect on the distribution of organic pollutants. Water Res. 2020;174;115634-115640.

4. Crawford CB, Quinn B. The biological impacts and effects of contaminated microplastics. Microplastic Pollut. 2017;159-178.

5. Enyoh CE, Shafea L, Verla A, et al. Microplastics Exposure Routes and Toxicity Studies to Ecosystems: An Overview. Environ. Anal. Health. Toxic. 2020;35;1-10.

6. Andrady AL. Microplastics in the marine environment. Mar. Pollut. Bull. 2015;62;1596-1605.

7. Winkler A, Santo N, Ortenzi MA, et al. Does mechanical stress cause microplastic release from plastic water bottles? Water Res. 2019;166;115082-115093.

8. He P, Chen L, Shao L, Zhang H, Lü F. Municipal solid waste (MSW) landfill: A source of microplastics? -Evidence of microplastics in landfill leachate. Water Res. 2019;159;38-45.

9. Paredes M, Castillo T, Viteri R, Fuentes G, Bodero E. Microplastics in the drinking water of the Riobamba city, Ecuador. Sci. Rev. Eng. Environ. Sci. 2019; 28:653-663.

10. Herrero Ó, Morcillo G, Planelló R. Transcriptional deregulation of genetic biomarkers in Chironomus riparius larvae exposed to ecologically relevant concentrations of di(2-ethylhexyl) 
phthalate (DEHP). PLoS One. 2017;12;e0171719.

11. Chao UHK, de Toledo RA, Shim H. Enhanced hybrid removal of DEHP from contaminated water using Acinetobacter sp. immobilized on scrap tyres. Energy Procedia. 2018;153;221-225.

12. Sienkiewicz M, Janik H, Borzędowska-Labuda K, Kucińska-Lipka J. Environmentally friendly polymer-rubber composites obtained from waste tyres: A review. J. Clean. Prod. 2017;147;560-571.

13. Herrero Ó, Morcillo G, Planelló R. Toxicidad del plastificante tipo DEHP en invertebrados. PLoS One. 2017;12;e0171719.

14. Hou Y, Zhang H, Wu J, Xiong H. Study on the microscopic friction between tire and asphalt pavement based on molecular dynamics simulation. Int. J. Pavement Res. Technol. 2018;11; 205-212.

15. Verla AW, Enyoh CE, Verla EN, Nwarnorh KO. Microplastic-toxic chemical interaction: a review study on quantified levels, mechanism and implication. SN Appl. Sci. 2019;1;1-38.

16. Ma Y, Hao S, Zhao H, Fang J, Zhao J, Li X. Pollutant transport analysis and source apportionment of the entire non-point source pollution process in separate sewer systems. Chemosphere 2018;211;557-565.

17. Clark I. Sampling and Analysis. Groundw. Geochem. Isot. 2015;381-402.

18. ISO. ISO 5667-3, Water quality-Sampling-Part 3: Preservation and handling of water samples, in ICS $>13>13.060>13.060 .45$, 5th ed., I. 147/SC 6 S. (general Methods), Ed. Geneva. 2018, p.52.

19. Rojo EN, Montoto T. Basuras marinas, plásticos y microplásticos orígenes, impactos y consecuencias de una amenaza global.
Madrid: Ecologistas en Acción; 2017. p. 92-101.

20. Chen G, Feng Q, Wang J. Mini-review of microplastics in the atmosphere and their risks to humans. Sci. Total Environ. 2020;703;135504-1355010.

21. Lares M, Ncibi MC, Sillanpää M. Occurrence, identification and removal of microplastic particles and fibers in conventional activated sludge process and advanced MBR technology. Water Res. 2018;133;236-246.

22. Talvitie J, Mikola A, Koistinen A, Setälä O. Solutions to microplastic pollution - Removal of microplastics from wastewater effluent with advanced wastewater treatment technologies. Water Res. 2017;123;401-407.

23. Raju S, Subash C, Carbery M, Kuttykattil A, Senathirajah K. Transport and fate of microplastics in wastewater treatment plants: implications to environmental health. Rev. Environ. Sci. Biotechnol. 2018;17;637-653.

24. Leslie HA, Brandsma SH, Velzen MJM, Vethaak AD. Microplastics en route: Field measurements in the Dutch river delta and Amsterdam canals, wastewater treatment plants, North Sea sediments and biota. Environ. Int. 2017; 101;133-142.

25. Kim HH, Kim DG, Choi JY, Park SC. Tire mixing process scheduling using particle swarm optimization. Comput. Ind. Eng. 2017;110;333-343.

26. Verla EN, Verla AW, Enyoh CE. Finding a relationship between physicochemical characteristics and ionic composition of River Nworie, Imo State, Nigeria. Peer J. Anal. Chem. 2020;2;5-20.

27. Liu CW, Lin KH, Kuo YM. Application of factor analysis in the assessment of groundwater quality in a blackfoot disease area in Taiwan. Sci. Total Environ. 2003;313;77-89. 